\title{
Narcoterrorism dan Perdagangan Senjata Ilegal sebagai Penghubung Jaringan Terorisme Internasional
}

\author{
Lalu Putrwandi Karjaya, Mohammad Sood, Purnami Safitri \\ Program Studi Hubungan Internasional \\ Universitas Mataram, Nusa Tenggara Barat - Indonesia \\ Email: putrawandi@unram.ac.id \\ Diserahkan: 15 April 2018, Diterima: 23 Mei 2018
}

\begin{abstract}
The international terrorism usually has intercourse with the illegal trade to available funds them that group can survive. Various terrorist network generally has a very different ways with the others, so it was hard to figure relation between one and the other. Nevertheless, in a manner funding had then we can see how a terrorist network was in a continent can be connected with terrorists in other continents through this funding. Terrorist financing itself obtained from illegal trade like as drug trafficking and illegal weapons. Drug trafficking by terrorists is then called narcoterrorism where business assisted by user in the world. The user uses the links between terrorist networks on the continents.
\end{abstract}

Keywords: Terrorism, Narcoterrorism, Illegal, Trade, Weapon.

\begin{abstract}
Abstrak
Jaringan Terorisme Internasional biasanya memiliki hubungan dengan dunia gelap untuk masalah pendanaan mereka agar kelompoknya dapat tetap bertahan. Berbagai jaringan teroris umumnya memiliki tujuan yang berbeda-beda sehingga akan sulit untuk mencari hubungan antara satu dan lainnya. Namun, melalui cara pendanaan mereka maka kita dapat melihat bagaimana suatu jaringan teroris yang berada di suatu benua dapat terhubung dengan teroris di benua lainnya melalui jaringan pendanaan ini. Pendanaan teroris ini sendiri didapatkan dari bisnis-bisnis ilegal seperti perdagangan narkoba dan senjata ilegal. Perdagangan narkoba oleh para teroris ini kemudian disebut narcoterrorism dimana bisnisnya dibantu oleh kartel-kartel di berbagai belahan dunia. Kartel-kartel inilah yang kemudian menghubungkan antara jaringan teroris di berbagai benua.
\end{abstract}

Kata Kunci: Terrorism, Narcoterrorism, Ilegal, Perdagangan, Senjata.

\section{PENDAHULUAN}

Isu-isu internasional dewasa ini berkembang dengan sangat pesat dan dinamis, terus berubah dari waktu ke waktu dan membawa perkembangan baru di setiap negara untuk menyelesaikan masalah yang juga dibawa oleh isu ini. Isu dan permasalahan ini muncul bersamaan dengan berbagai peristiwa yang terjadi dengan sangat cepat tanpa diduga bahkan prediksi. Permasalahan yang membawa ancaman ini, dapat berupa ancaman ekonomi, politik bahkan keamanan internasional. Di dalam proses untuk mencapai sebuah kondisi keamanan yang diinginkan tidak akan 
terlepas dari banyaknya kendala yang harus dihadapi. Kendala tersebut tidak lain adalah perang, kudeta politik, kejahatan manusia bahkan kejahatan transnasional.

Kejahatan transnasional telah menjadi salah satu tantangan yang memberikan pengaruh yang besar terhadap stabilitas kemanan internasional. Perdagangan serta penyelundupan manusia, senjata, dan obat-obatan terlarang dan pencucian uang yang melintasi batas teritori suatu negara merupakan ancaman yang dinilai sangat berbahaya di mana pada akhirnya menimbulkan efek domino yang berimbas pada sektor lain dalam kerangka stabilitas keamanan internasional. Terorisme kemudian mucul sebagai ancaman terhadap keamanan internasional yang menjadi sarana bagi sekelompol kepentingan dengan tujuan politis tertentu yang menggunakan kekerasan dan teror sebagai alat dalam mencapai kepentingan mereka. Di dalam melancarkan aksinya, teroris tidak segan-segan untuk melakukan praktik kriminal lain, seperti perdagangan manusia, senjata, dan narkoba, penculikan, perampokan hingga pencucian uang. Hasil-hasil dari tindak kriminalitas tersebut pada akhirnya menjadi income atau pemasukan dana bagi kelompok teroris.

Berbagai tindak kriminal di atas, secara tidak langsung telah menghubungkan berbagai jaringan terorisme di dunia. Corak gerakan jaringan terorisme transnasional ini dapat dilihat dari tindakan kriminal yang bermula demi meraih dana bagi kelompok yang berujung tindakan kriminal lainnya demi menjalankan aksi teror. Di dalam tulisan ini, tindakan kriminal demi meraih dana lebih difokuskan pada perdagangan obat-obatan terlarang atau narcoterrorism, sedangkan tindakan kriminal yang akan memfasilitasi aksinya adalah perdagangan senjata, di mana baik perdagangan obat-obatan terlarang maupun senjata tersebut seakan 'dipenuhi' oleh sebuah kelompok atau organisasi kriminial lainnya. 
Narcoterrorism sendiri pertama kali ditemukan di kawasan Amerika Latin dengan anggota mafia sebagai penggerak aksi tersebut. Keuntungan yang didapat juga terhitung besar mengingat kondisi Amerika Latin yang masih rawan akan tindak kriminalitas. Bermula dari gerakan yang melawan pemerintah, narcoterrorism pada akhirnya mulai digunakan oleh kelompok teroris, Al-Qaeda menjadi sarana penggalangan dana akibat mimimnya dukungan dari Negara pendukung kebutuhan mereka (state supporting terrorism). Selain itu juga dapat dikarenakan mereka ingin memperkuat posisinya dan memberikan berbagai akses yang dapat memberikan mereka perlindungan maupun bantuan dalam mempermudah mereka mencapai tujuan yang diinginkan.

Baik narcterrorism maupun perdagangan senjata antara organisasi kejahatan transnasional dan organisasi terorisme transnasional telah memodifikasi kedua benda tersebut melalui proses produksi dan distribusi dalam kerja sama yang terorganisir demi meraih keuntungan yang semaksimal mungkin. Besarnya keinginan kelompok teroris tersebut dalam meraih tujuannya membuat mereka begitu gencar dalam melaksanakan aksi terornya. Banyaknya jumlah aksi teror yang ingin dilancarkan, maka semakin besar pula kebutuhan mereka akan dana dan persenjataan.

Banyaknya tindakan teror di berbagai benua terlihat memiliki pergerakan dan persebaran yang acak dan sulit untuk diprediksi. Satu kelompok teroris dapat pecah menjadi dua kelompok yang berbeda dan menjadi rival. Ada juga beberapa kelompok teroris yang berbeda bergabung menjadi satu disebabkan pernikahan antar putra-putri pemimpin kelompok terkait, atau beberapa kelompok radikal kecil yang ingin berlindung di bawah kelompok yang lebih besar sehingga mereka bergabung sebagai partner. Nama yang berbeda, pergerakan yang berbeda membuat kelompok-kelompok teroris tersebut semakin sulit untuk diprediksi pergerakannya. Tetapi ada satu hal 
yang pasti yaitu mereka tetap membutuhkan dana dan senjata. Dana dan senjata tersebut pada akhirnya dapat dipenuhi melalui kerja samanya dengan triad.

Triad sendiri merupakan sebuah sindikat kejahatan transnasional terorganisir yang berasal Tiongkok dengan basis yang berada di seluruh dunia. Sindikat kejahatan ini seakan telah menjadi sarana penghubung bagi seluruh kelompok teroris di lima benua, Amerika, Eropa, Afrika, Asia dan Australia. Meskipun kelompok ini berasal dari Tiongkok, namun basisnya telah tersebar di seluruh dunia dengan memanfaatkan diaspora populasi Cina yang terhitung signifikan, seperti Amerika Serikat, Kanada (Benua Amerika), Belanda, Inggris, Belgia, Perancis, Spanyol (Benua Eropa), Kawasan Afrika Selatan (Benua Afrika), Korea, Jepang, Singapura, Indonesia, Filipina, Malaysia, Thailand, Vietnam, Taiwan, Singapura (Benua Asia), Australia dan Selandia Baru (Benua Australia).

\section{JARINGAN TERORISME INTERNASIONAL}

Sesungguhnya

terorisme

bukanlah merupakan isu baru di dunia internasional. Perkembangan terorisme beserta jaringannya tidak dapat dilepaskan dari dinamika politik luar negeri dan politik domestik. Terorisme ini juga bukan merupakan sebuah paham, namun sebuah gerakan. Di dalam skenario gerakan, efektivitas tindakan memiliki berbagai variasi strategis dan simbolis. Secara strategis, bom mobil ataupun bom bunuh diri dapat menghancurkan target serangan, dan secara simbolis memberikan tanda keberadaan gerakan teroris. Simbolisme dalam ranah teroris ini memiliki karakter mengecoh. Kecohan pertama langsung terkait dengan atribut ideologis. Dalam kondisi ini gerakan terorisme menjadi rumit, karena terorisme selalu berkembang, dan tidak selamanya terkait atau tidak terkait dengan ideologi manapun. Jika aparat keamanan dan pemerintah tergiring untuk fokus ke dalam kecohan tersebut, maka dapat dikatakan strategi 
yang digunakan teroris ini sukses dijalankan (Kuncahyo, 2013:7). Dengan dukungan perkembangan dan kemajuan teknologi, potensi jejaring dan daya jangkau serangannya membuat terorisme memiliki ruang untuk berkembang dan menjadi ancaman di Internasional (Wuryandari, 2014, 20).

Berikut beberapa kelompok teroris yang lahir dan, atau berkembang di Benua Asia, Afrika, Eropa, dan Amerika.

\section{Boko Haram (Afrika)}

Asal Boko Haram terletak pada sekelompok pemuda Islam radikal yang dipuja di Masjid Alhaji Muhammadu Ndimi di Maiduguri satu dekade lalu. Pada tahun 2002, sebuah cabang dari kelompok pemuda ini (belum dikenal sebagai Boko Haram) menyatakan pendirian kota Islam. Mereka kemudian melakukan hijrah dan pindah dari Maiduguri ke sebuah desa bernama di Kanama, Yobe, dekat perbatasan dengan Niger, untuk mendirikan sebuah komunitas yang menjalankan separatis pada prinsip- prinsip Islam garis keras.

Pemimpinnya, Mohammed Ali, didukung ideologi anti-state dan menyerukan umat Islam lainnya untuk bergabung dengan grup dan kembali ke kehidupan di bawah hukum Islam dengan tujuan membuat masyarakat yang lebih sempurna dari pemerintahan korup (Sahisnu, 2017). Pada bulan Desember 2003, setelah sengketa masyarakat mengenai hak memancing di kolam lokal, kelompok tersebut terlibat konflik dengan polisi.Anggota kelompok mengalahkan skuad petugas dan mengambil senjata mereka. Konfrontasi ini menyebabkan pengepungan masjid oleh tentara yang berlangsung sampai tahun baru. Pengepungan berakhir dalam tembakmenembak di mana sebagian besar anggota tujuh puluh kelompok tewas, termasuk Mohammed Ali (A. Walker, 2012).

Kelompok ini telah memperoleh perhatian pers di Nigeria, dan menarik perhatian dari Kedutaan Besar AS, karena nama yang menarik penduduk setempat telah diberikan: Nigeria 
Taliban. Hal ini juga menarik perhatian media Nigeria karena banyak anggota kelompok adalah anak-anak orang kaya dan berpengaruh dalam pembentukan utara Nigeria.Pada tahun 2004 Departemen Luar Negeri AS, diungkapkan oleh Wikileaks, Kedubes AS di Abuja menyimpulkan kelompok tidak menyajikan ancaman internasional dan kemungkinan tidak memiliki hubungan dengan organisasi jihad internasional (A.Walker, 2012).

Beberapa orang yang selamat dari "Nigeria Taliban" kembali ke Maiduguri, di mana mereka menetap kembali dengan orang lain dari kelompok pemuda yang berasal di masjid Ndimi. Pemimpin kelompok Maiduguri ini, Mohammed Yusuf, kemudian memulai proses pembentukan kelompok masjid sendiri di Maiduguri.Ini masjid baru, bernama Ibn Taimiyyah. Masjid tersebut dibangun di atas tanah di sebelah utara pusat kota, dekat stasiun kereta api, yang dimiliki oleh Yusuf ayah mertua, Baba Fugu Muhammad. Kelompok ini tampaknya dibiarkan saja oleh pemerintah, dan diperluas ke negara- negara lain, termasuk Bauchi, Yobe, dan negara Niger.Tetangga kelompok di Maiduguri dijuluki kelompok Boko Haram, yang secara kasar diterjemahkan sebagai "Pendidikan Barat dilarang" di Hausa (African Union, Boko Haram, 2017).

Ini menarik lebih banyak orang di bawah atap dengan menawarkan handout kesejahteraan, pangan, dan papan. Banyak orang kelompok yang tertarik adalah pengungsi dari perang di perbatasan Chad dan pemuda Nigeria pengangguran.Sumber uang kelompok pada tahap ini keberadaannya tidak jelas. Anggota pembentukan agama Borno mengatakan bahwa Yusuf menerima dana dari kontak Salafi di Arab Saudi setelah dua perjalanan haji yang dilakukan Yusuf selama ini. Kemungkinan sumber dana selama periode ini adalah sumbangan dari Nigeria Utara yang kaya. Pada tahun 2006, seorang pengusaha kaya Utara ditangkap oleh Jasa Keamanan Negara setelah sekelompok anak-anak menuduh bahwa mereka telah dikirim oleh kelompok untuk sebuah kamp 
pelatihan

al-Qaeda

di

Mauritania.Pengusaha

tersebut

mengatakan sumbangan kepada

kelompok itu merupakan upaya yang

tidak bersalah untuk berkontribusi zakat, kewajiban umat Islam kaya memberi dengan murah hati (A. Walker. 2012).

Pada malam pemilihan presiden tahun 2007, Sheikh Mahmoud Ja'afar Adam, seorang ulama terkemuka dan populer pengkhotbah rutin di masjid Ndimi di Maiduguri, dibunuh saat ia sedang sembahyang di masjid yang didirikan di Kano. Pembunuhan itu adalah misteri selama beberapa waktu, tetapi sekarang diakui bahwa itu dilakukan atas perintah Muhammad Yusuf. Sheikh Ja'afar mulai mengkritik kelompok ideologi garis keras yang, memprediksi bentrokan dengan negara.Pembunuhan ini sekarang dipandang oleh beberapa sebagai titik kunci dalam pengembangan Boko Haram, karena tidak ada lagi kemungkinan untuk mengubah Yusuf dan para pengikutnya kembali ke arus utama pendirian Islam utara (A. Walker. 2012).
Tulisan ini menjelaskan mengenai beberapa kelompok terorisme internasional, triad yang membantu kelompok-kelompok tersebut dalam narcoterrorism dan perdagangan senjata serta memaparkan bagaimana kelompokkelompok teroris yang berada di lima benua dapat terhubung melalui alur pendanaan dan persenjataan melalui Triad sebagai penghubungnya.

\section{Al Qaeda (Asia, Afrika, Eropa)}

Al-Qaeda adalah jaringan teroris internasional yang dipimpin oleh Usama Bin Laden [yang "Osama" adalah ejaan usang, karena tidak ada huruf "O" dalam bahasa Arab). Didirikan sekitar 1988 oleh bin Laden, al-Qaeda membantu keuangan, merekrut, transportasi dan melatih ribuan bertahap dari puluhan negara menjadi bagian dari Afghanistan tahan untuk mengalahkan Uni Soviet. Untuk melanjutkan jihad di luar Afganistan, al-Qaeda saat ini tujuannya adalah untuk membentuk suatu ketikaKhalifah Islam di seluruh dunia dengan bekerjasama dengan sekutu 
kelompok ekstremis Islam untuk menjatuhkan rezim yang dianggapnya "non-Islam" dan membuang Barat dan non-Muslim dari Muslim negara (J.T. Caruso, Al-Qaeda Internasional, 2001).

Pada bulan Februari 1998, alQaeda mengeluarkan pernyataan di bawah spanduk dari "Front Dunia Islam bagi Jihad terhadap orang-orang Yahudi dan memeluk" mengatakan adalah kewajiban semua Muslim untuk membunuh warga AS-sipil atau militer-dan sekutu mereka di manamana. Al-Qaeda akan bergabung dengan Jihad Islam Mesir (Al-Jihad) dari Ayman al-Zawahiri pada bulan Juni 2001 J.T. Caruso, Al-Qaeda Internasional, 2001).

Setelah al-Qaeda's 11 September 2001, serangan di Amerika, Amerika Serikat meluncurkan perang di Afghanistan untuk memusnahkan alQaeda's ada dasar dan menggulingkan Taliban, negara Islam fundamentalis pemimpin yang harbored bin Laden dan pengikutnya. "Al-Qaeda" adalah Bahasa Arab untuk "dasar". Dalam sebuah rumah al-Qaeda di Afganistan, wartawan New York Times ditemukan sebuah pernyataan singkat dari "Tujuan dan Tujuan jihad" antara lain; melakukan supremasi Allah di muka bumi; mencapai syahid di jalan Allah; kesucian yang menempati urutan Islam dari unsur-unsur dari kerusakan moral.

Pada tahun 1998, beberapa pemimpin al-Qaeda mengeluarkan pernyataan panggil untuk membunuh Muslim di Amerika-termasuk warga sipil sebagai "orang-orang yang dengan sekutu di antara mereka penolong dari Setan". Tactics termasuk pembunuhan, bom, perampokan, penculikan, serangan bunuh diri. Sejumlah laporan dan publik Bin Laden proclamations menunjukkan keinginan kuat untuk memperoleh dan memanfaatkan biologi, kimia dan senjata nuklir. Sasaran cenderung menonjol simbol (gedung-gedung publik, kedutaan dan personil militer, dll) dari Amerika Serikat, para sekutu, dan pemerintah Muslim moderat. Menurut mantan Direktur CIA George J. pendapat, "Usama Bin 
Ladin's organisasi dan kelompok teroris lainnya adalah menempatkan penekanan pada peningkatan pengembangan surrogates untuk melakukan serangan dalam upaya untuk menghindari deteksi. Misalnya, Jihad Islam Mesir (EIJ) adalah terkait erat untuk Bin Ladin's organisasi dan telah operatives berlokasi di seluruh dunia-termasuk di Eropa, Yaman, Pakistan, Lebanon, dan Afganistan. Sekarang ada yang rumit web dari aliansi antara ekstrimis Sunni di seluruh dunia, termasuk Afrika Utara, Palestina radikal, dan Asia Tengah. Beberapa dari teroris ini sedang aktif disponsori oleh pemerintah nasional yang antipati menuju pelabuhan besar Amerika Serikat.

Adalah mustahil untuk diketahui secara tepat, karena adanya desentralisasi struktur organisasi. AlQaida mungkin memiliki beberapa ribu anggota dan asosiasi. Ini tentunya lebih dari 5.000 orang dilatih di kamp di Afghanistan sejak akhir tahun 1980an. Ia juga bertindak sebagai titik fokus untuk jaringan di seluruh dunia yang mencakup banyak kelompok ekstremis
Islam Sunni, beberapa anggota alGama'a al-Islamiyya, Gerakan Islam Uzbekistan, dan Harakat ul-Mujahidin J.T. Caruso, Al-Qaeda Internasional, 2001).

\section{Abu Sayyaf (Asia)}

Pada awalnya Abu Sayyaf dikenal dengan nama al-Harkatul al-Islamiya. Diawal tahun 1980-an sekitar 300 sampai dan 500 fundamentalis Moro tiba di Pesawahan, Pakistan untuk membantu Mujahidin yang sedang melawan invasi dan pendudukan Uni Soviet ke Afghanistan. Salah seorang dari mereka, Abdurajak Janjalani muncul sebagai pemimpin saat itu.

Secara historis, Kelompok Abu Sayyaf didirikan sekitar tahun 1990 oleh Abdurajak Abu Bakar Janjalani, yang semakin radikal setelah bepergian ke negara-negara Timur Tengah. Tahun 1988, Janjalani dilaporkan berjumpa Osama Bin Laden di Pakistan dan berjuang bersama melawan invasi Soviet di Afghanistan. Setelah itu, Janjalani mulai mengembagkan misinya untuk mengubah Filipina Selatan menjadi 
negara Islam. Untuk menjalankan misinya ini Janjalani merekrut anggota dari Front Pembebasan Nasional Moro (MNLF) yang kecewa dengan organisasi MILF atau Front Pembebasan Islam Moro (Deutsche Welle, 2016).Eks-MNLF ini dkenal lebih radikal dalam ideologi mendirikan negara Islam independen dari pada mantan organisasi induknya. Sasaran Kleompok Abu Sayyaf adalah sebagaimana yang sudah disampaikan yaitu menjadikan para militer dan WNA sebagai sasaran kekerasan, penculikan, pemboman, dan seranganserangan yang sejenis.

Abu Sayyaf memiliki sebuah tipe kepemimpinan yang ditempatkan pada setiap titik wilayah yang memungkinkan pergerakan namun tetap terdapat satu pimpinan tertinggi. Artinya, Abu Sayyaf menjadi sebuah gerakan terorisme yang cukup terorganisir. Berdasarkan informasi terbaru saat ini yang memimpin $\mathrm{Abu}$ Sayyaf adalah Alhabsy Misaya yang tewas terbunuh pada saat operasi pembebasan beberapa sandera yang salah satunya merupakan sandera asal
Indonesia. Hingga sekarang masih belum diketahui siapa yang akan menjadi pimpinan tertinggi Abu Sayyaf berikutnya.

Kelompok Abu Sayyaf adalah sebuah kelompok gerakan radikal yang memiliki basis operasi di Filipina Selatan. Namun, pergerakannya semakin ekspansif sehingga mulai memasuki perbatasan wilayah Negara di Asia Tenggara yakni Indonesia, Philipina bahkan Malaysia. Perbatasan perairan menjadi basis internasional pergerakan Kelompok Abu Sayyaf yang menjadikan kapal-kapal yang melintas di perairan tersebut sebagai sasaran operasinya. Sehingga, Kelompok Abu Sayyaf juga disebut sebagai "terorisme maritim". Adanya pergerakan yang melewati lintas batas Negara menjadikan Kelompok Abu Sayyaf sebagai jaringan terorisme internasional dan menjadi permasalahan bersama yang harus diselesaikan dengan idiologi yang dikembangkan bersifatradikal, dimana gerakan ini selalu menggunakan kekerasan dalam setiap aksinya. Dengan setiap tindakan yang 
dilakukan seperti pembajakan, penyanderaan dan eksekusi mati sandera telah mengarahkanya menjadi pelaku teror. Sehingga wajar apabila Abu Sayyaf dianggap sebagai sebuah kelompok pemberontak (terorisme) karena aksinya yang dapat mengancam korban dan keutuhan suatu negara. Ideologi gerakan yang sifatnya radikal inilah yang kemudian menjadi dasar dalam bertindak oleh Abu Sayyaf.

\section{Jamaan Islamiyah (Asia)}

Jamaah Islamiyah atau yang selanjutnya disingkat JI pertama kali didirikan oleh Abdullah Sungkar dan Abu Bakar Ba'asyir serta Thoriqudin alias Hamzah yang disebut-sebut turut membantunya dalam membentuk jaringan JI. Abdullah Sungkar dan Abu Bakar Ba'asyir merupakan ekstremis Indonesia yang melarikan diri ke Malaysia pada tahun 1985. Tujuan mereka mebentuk JI adalah iqomatudien (menegakkan syariat islam) lewat jalan jihad fisabilillah.

Terpengaruhnya JI karena beberapa personel JI sendiri dan personel Al-Qaeda yang berada di
Afghanistan ketika itu. Di bawah pengaruh Al-Qaeda Ji banyak timbul keyakinan bahwa tujuan untuk mendirikan negara Islam hanya bisa dicapai dengan jalan "perang suci" (Ayub, t.t). Adanya keterhubungan JI dengan Al-Qaeda tidak dapat dipingkiri, JI adalah "sayap Al-Qaeda di Asia Tenggara" kehadiran kaum militan Asia Tenggara secara bersamaan di kamp-kamp Al-Qaeda di Afghanistan yang menyebabkan terjadi hubungan pribadi antara JI dengan dan kelompok-kelompok Islam garis keras Asia Tenggara. Kelompok itu adalah Front Pembebasan Islam Moro (Moro Islamic Liberation Front) yang memperjuangkan negara Muslim di Filipina Selatan dan sejumlah kelompok Indonesia, Malaysia dan Thailand. Hal ini mengisyaratkan bahwa meski sebagian personel JI terinspirasi oleh tokoh global seperti Usamah Bin Laden, kelompokkelompok Asia Tenggara tetap berbeda secara organisasi dan operasi. Jamaah Islamiyah dipimpin oleh seorang amir yang berkedudukan di Markaz atau markas. Banyak sekali 
petinggi dari JI yang dituntut oleh pengadilan atas kasus terorisme. Sehingga kepemimpinan JI banyak mengalami pergantian. Namun, sampai saat ini pergantian kepemimpinan JI selalu rahasia. Misalkan pada tahu 2008 polisi menunjuk satu nama yang dianggap menjadi pemimpin Ji yakni Abu Huzna yang merupakan adik dari Abu Fatih bekas ketua Mantiqi 2 JI (Amrullah, 2008).Selain itu juga pada tahun 2015 FBI yang turut andil dalam menangani masalah terorisme oleh JI mengumumkan Marwan Alias Zulkifli bin Hir alias Zulkifli Abdhir yang merupakan pimpinan tertinggi JI pada saat itu yang tewas terbunuh pada penyergapan di selatan Filipina (BBC, 2015).

Jaringan kelompok ini berkembang menjadi sel-sel yang tersebar di kepulauan Indonesia, Malaysia, Filipina, Singapura dan Thailand. Namun, tidak menutup kemungkinan terdapat sel-sel yang lebih kecil lagi di luar Asia Tenggara. Tujuan kelompok ini adalah mendirikan satu negara Islam di
Indonesia dan wilayah lain Asia Tenggara. Di tahun-tahun awal pembentukannya JI sempat menyarankan penggunaan jalan damai dalam usaha mencapai tujuannya, namun pada pertengahan tahun 1998 kelompok ini mulai menggunakan jalan kekerasan karena sebagian dari anggotanya terpengaruh dengan fatwa Usamah Bin Laden.

Salah satu bukti keberadaan JI dan aktivitas jihadnya di Indonesia ditemukan di desa Sayangan Solo. Barang bukti yang ditemukan di rumah berukuran $3 \times 3,5 \mathrm{~m}$ itu adalah bukubuku berjudul: Pedoman Umum Perjuangan Jamaah Islamiyah, Pembentukan Sikap Dasar Jamaah Islamiyah Laporan PTA Ymuq Dauru I, Cara Membuat Bom, Islamic Military of Jemaah Islamiyah, serta 16 buku kemiliteran (Fahrudin, t.t, p. 5).

\section{Taliban (Asia)}

Gerakan Taliban, atau Taliban atau Taleban (Bahasa Persia dan

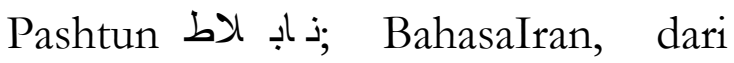
bentuk jamak Bahasa Arab bل بtạ̄lib, "murid"), adalah gerakan nasionalis 
Islam Sunni pendukung Pashtun yang secara efektif menguasai hampir seluruh wilayah Afganistan sejak 1996 sampai 2001. Kelompok Taliban dibentuk pada September 1994, mendapat dukungan dari Amerika Serikat dan Pakistan. Dewan Keamanan PBB mengecam tindakan kelompok ini karena kejahatannya terhadap warga negara Iran dan Afghanistan. Taliban melakukan berbagai aksi pelanggaran HAM di Afghanistan.

Kelompok ini mendapat pengakuan diplomatik hanya dari tiga negara: Uni Emirat Arab, Pakistan, dan Arab Saudi, serta pemerintah Republik Chechnya Ichkeria yang tidak diakui dunia. Anggota-anggota paling berpengaruh dari Taliban, termasuk Mullah Mohammed Omar, pemimpin gerakan ini, adalah mullah desa (pelajar yunior agama Islam), yang sebagian besar belajar di madrasah di Pakistan. Gerakan ini terutama berasal dari Pashtun di Afganistan, serta Provinsi Perbatasan Barat Laut (North-West Frontier Province, NWFP) di Pakistan, dan juga mencakup banyak sukarelawan dari Arab, Eurasia, serta Asia Selatan. Pemerintahan Taliban digulingkan oleh Amerika Serikat karena dituduh melindungi pemimpin Al Qaeda Osama Bin Laden yang juga dituduh Washington mendalangi serangan terhadap menara kembar WTC, New York pada tanggal 11 September 2001 bekerja sama dengan kubu Aliansi Utara. Invasi ini dimulai pada bulan Oktober sampai dengan bulan November 2001 dengan secara mengejutkan sehingga pihak Taliban langsung keluar dari ibukota Afganistan, Kabul sehingga pihak Amerika relatif cepat dan mudah menguasainya. Akan tetapi beberapa tahun setelahnya American Free Press mengungkapkan hal sebaliknya, yaitu keterlibatan CIA dan agen intelijen Israel, Mossad dalam peristiwa serangan 11 September 2001 hanyalah skenario untuk mengakuisisi negaranegara arab, dalam hal ini Irak dan Afghanistan.

Cikal bakal gerakan ini adalah pesantren dengan sumber dana dari Arab Saudi. Pesantren ini biasanya 
menganut aliran Sunni garis keras. Janji

Taliban di wilayah-wilayah kediaman warga Pashtun, yang tersebar di Pakistan dan Afghanistan, adalah memulihkan perdamaian dan keamanan berdasarkan Syariah Islam jika mereka berkuasa. Di kedua negara itu mereka memberlakukan atau mendukung hukum Islam, seperti eksekusi di depan umum untuk kasus pembunuhan dan perzinahan serta potong tangan bagi para pencuri. Diberlakukan juga aturan pakaian yang ketat, seperti perempuan yang menggunakan burka atau pria yang harus memelihara janggut. Dalam Taliban, tidak memperbolehkan televisi, musik, dan bioskop serta melarang anak-anak perempuan berusia 10 tahun ke atas masuk sekolah.

\section{ISIS (ASIA)}

Negara Islam Irak dan Suriah Islamic States of Iraq and Suriah ISIS merupakan kelompok Jihadis yang aktif di Irak dan Suriah. ISIS dibentuk pada April 2013 dan cikal bakalnya berasal dari al-Qaida di Irak (AQI), tetapi kemudian dibantah oleh alQaida. Kelompok ini menjadi kelompok jihad utama yang memerangi pasukan pemerintah di Suriah dan membangun kekuatan militer di Irak. Huruf "S" dalam singkatan ISIS berasal dari bahasa arab "al-Sham", yang merujuk ke wilayah Damaskus (Suriah) dan Irak. Tetapi dalam konteks jihad global disebut Levant yang merujuk kepada wilayah di Timur Tengah yang meliputi Israel, Yordania, Lebanon, wilayah Palestina, dan juga wilayah Tenggara Turki. Jumlah mereka tidak diketahui secara pasti, tetapi diperkirakan memiliki ribuan pejuang, termasuk jihadis asing (National Geographic, 2014).

Organisasi ini dipimpin oleh Abu Bakar al-Baghdadi. Hanya sedikit yang mengetahui tentang dia, tetapi dia diyakini lahir di Samarra, bagian utara Baghdad, pada 1971 dan bergabung dengan pemberontak yang merebak sesaat setelah Irak diinvasi oleh AS pada 2003 lalu. Pada 2010 dia menjadi pemimpin al-Qaida di Irak, salah satu kelompok yang kemudian menjadi ISIS. Baghdadi dikenal sebagai 
komandan perang dan ahli taktik, analis mengatakan hal itu yang membuat ISIS menjadi menarik bagi para jihadis muda dibandingkan AlQaeda, yang dipimpin oleh Ayman alZawahiri, seorang teolog Islam. Prof Peter Neumann dari King's College London memperkirakan sekitar 80\% pejuang Barat di Suriah telah bergabung dengan kelompok ini ('Syria Iraq: The Islamic State Militant Group, 2014). ISIS mengklaim memiliki pejuang dari Inggris, Prancis, Jerman, dan negara Eropa lain, seperti AS, dunia Arab dan negara Kaukakus. Tak seperti pemberontak di Suriah, ISIS tampak akan mendirikan kekhalifahan Islam di Suriah dan Irak. Kelompok ini tampak berhasil membangun kekuatan militer. Pada 2013 lalu, mereka menguasai Kota Raqqa di Suriah - yang merupakan ibukota provinsi pertama yang dikuasai pemberontak. Juni 2014, ISIS juga menguasai Mosul, yang mengejutkan dunia. AS mengatakan kejatuhan kota kedua terbesar di Irak merupakan ancaman bagi wilayah tersebut. Kelompok ini mengandalkan pendanaan dari individu kaya di negara-negara Arab, terutama Kuwait dan Arab Saudi, yang mendukung pertempuran melawan Presiden Bashar al-Assad. Saat ini, ISIS disebutkan menguasai sejumlah ladang minyak di wilayah bagian timur Suriah, yang dilaporkan menjual kembali pasokan minyak kepada pemerintah Suriah (NU, 2018).

\section{Pendanaan Jaringan Terorisme}

Keuangan menjadi salah satu hal terpenting individu maupun organisasi di dunia demi bertahan hidup, tidak terkecuali kelompok teroris. Ada berbagai macam sumber pendanaan yang digunakan dengan metode legal maupun illegal. Raphaeli menyebutkan bahwa yang disebut sebagai organisasi amal, secara umum sering digunakan oleh teroris sebagai kedok untuk memobilisasi dana dan berfungsi sebagai saluran uang. Uang ini sendiri diibaratkan sebagai mesin yang menggerakkan tindakan teroris, sehingga tidaklah heran apabila pendanaan terorisme menjadi masalah yang serius sehingga butuh kepedulian 
terhadap berbagai pihak yang bertanggung jawab untuk melacak, mencegat dan jika mungkin dalam upaya mencegah aksi terorisme. Secara umum, metode penggalangan dana seringkali bercampur dengan uang dari sumber yang legal dan illegal yang hampir sulit untuk dibedakan. Di satu sisi, dana dapat berasal dari penggalangan amal yang sah, dan di sisi lainnya berasal dari penipuan kartu kredit, penyelundupan, dan bisnisbisnis illegal tertentu. Secara umum pendanaan terorisme meliputi sejumlah tujuh hal.

Pertama, Zakat, merupakan salah satu pilat pendanaan terorisme dengan tujuan memurnikan niat orang beriman melalui manifestasi sosial yang member manfaat bagi kaum yang kurang beruntung. Melalui organisasiorganisasi amal yang sah yang menampung zakat dan sedekah inilah teroris merasa aman untuk menjadikannya sebagai sarana pendanaan kegiatan operasional mereka; kedua, Hawala, merupakan suatu sistem transfer atau pengiriman uang dari satu pihak kepada pihak lain, tanpa penggunaan lembaga formal seperti uang atau institusi pengiriman uang formal. Hawala digunakan untuk transfer uang karena sering lebih cepat dan tidak meninggalkan jejak karena sifatnya yang informal; ketiga, rekening perantara di bank-bank Islam untuk menyembunyikan pergerakan uang dengan mendaftarkan atas nama organisasi alam atau individu anonym; keempat, penggunaan saluran diplomatik; kelima, bisnis legal maupun illegal; keenam, aktivitas kriminal; dan ketujuh, pembawaan uang secara tunai melintasi batas negara.

Sumber pendanaan terorisme bagi sebuah kelompok terror juga dapat diperoleh baik secara internal maupun eksternal. Pola pemikiran dalam mengambil keputusan untuk memilih dari mana datangnya dana untuk operasi teror akan melalui proses yang lebih spesifik melalui pembuatan kebijakan dalam kelompok terror. Proses pengambilan kebijakan dalam kelompok terror ini akan memiliki perhitungan dan pertimbanganpertimbangan 
tersendiri, inilah yang menyangkut perhitungan kekuatan dan kelemahan di masing-masing mekanisme dan pola pendanaan. Tinjauan tersendiri terhadap hal tersebut telah dilakukan oleh Matthew Levitt dalam artikelnya yang menggambarkan bagaimana sebuah kelompok bernama Hezbollah tidak bergantung pada sumber-sumber eksternal namun lebih mengutamakan dan mengupayakan upaya menghasilkan dana yang sifatnya mandiri, namun tidak menutup kemungkinan adanya alternatiF pendanaan lain antara lain; pertama, pengiriman uang dari ekspatriat asing yang memberikan kontribusi bagi kelompok tersebut, contohnya oleh Labanese Shia Expatriate Communitites; kedua, memanfaatkan organisasi alam untuk menyembunyikan aktivitas penggalangan dananya meskipun kurang bergantung pada organisasi tersebut seperti yang dilakukan kelompok Hamas. Hal ini disebabkan karena Hezbollah telah mendapatkan subsidi tahunan dari Iran dan memiliki keterlibatan signifikan dalam kegiatan kriminal, contohnya adalah Al-Aqaa International Foundation; ketiga, bergantung pada perusahaanperusahaan yang didirikan secara illegal milai dari penyelundupan, perdagangan narkotika hingga berlian secara internasional untuk menghasilkan dana bagi aktivitas kelompok terror ini. selain itu mereka juga terlibat dalam beberapa aksi perampokan secara lokal dan pendirian paper company yang berperan dalam menghasilkan dana dan aktivitas pencucian uang (Levitt, 2005, 2-11).

Hal ini menyebabkan adanya kemungkinan pola pendanaan mandiri menjadi pilihan terbaik bagi sebuah kelompok teror mengingat pilihanuntuk mendapatkan dana dari luar wilayah organisasi tersebut tidak lagi memungkinkan karena apabila tetap dijalankan akan mengancam keberadaan kelompok teror tersebut. Namun, tidak pula menutup kemungkinan aktivitas pendanaan dari sumber eksternal untuk dilakukan, yang tentunya menghasilkan dana yang lebih besar dibandingkan dana 
mandiri. Meski demikian, pendanaan eksternal ini sangatlah membutuhkan fasilitas dan SDM ahli dalam kelompok teror.

Ambillah contoh Abu Sayyaf Group (ASG), yang di mana kelompok ini mendapatkan dana eksternalnya dari kegiatan penculikan untuk tebusan dan juga telibat dalam penjualan ganja dan hidroklorida metamfetamin (sabu).

Beberapa

laporan mengindikasikan Abu Sayyaf menerima sejumlah besar uang yang dinilai signifikan melalui dukungan dari jaringan terorisme islam di seluruh dunia, yang di mana uang tersebut kemudian disalurkan melalui semiorganisasi amal yang sah yang berbasis di Manila. ASG juga sangat terkenal dengan tindakannya menculik turis asing yang datang ke Filipina, yang di mana pada akhirnya penculikan ini akan berujung pada datangnya uang tebusan dari negara terkait (Stanford University, t.t).

Selain dari penculikan tersebut, ASG juga mendapatkan dana dari penjualan obat-obatan terlarang. ASG membangun jaringan narkotika dengan the Hong Kong Triad 14-K yang mendukung persediaan persenjataan sebagai tukar menukar dengan penjualan sabu di Filipina. Penjualan obat-obatan terlarang methamphetamine bydrochide diproduksi secara local namun perkusor untuk obat umumnya diselundupkan keluar dari Tiongkok dengan menggunakan rute laut secara langsung ke Filipina.

\section{Narcoterrorism dan Perdagangan Senjata Ilegal}

Secara sederhana narcoterrorism didefinisikan sebagai aktivitas perdagangan obat-obatan terlarang yang di mana bertujuan untuk mendanai serangkaian aksi teror yang telah direncanakan dengan matang oleh kelompok-kelompok teroris di atas.Tidak hanya digunakan sebagai sarana untuk mendanai serangkaian aksi terror yang telah direncanakan, narcoterrorism juga dapat digunakan sebagai alat pendukung berlangsungnya perdagangan maupun pertukaran senjata illegal. Narcoterrorism sendiri menurut Drug Enforcement 
Agency (DEA) adalah (Hutchinson, 2002):

"participation of groups or associated individuals in taxing, providing security for, otherwise aiding or abetting drug trafficking endeavors in an effort to further, or fund, terrorist activities".

Definisi narcoterrorism di atas pada akhirnya dapat dijabarkan lebih lanjut sebagai upaya dari pihak-pihak tertentu, baik sebagai individu maupun organisasi tertentu, di mana mereka menyediakan akses-akses yang dapat mempermudah usaha-usaha dan aktivitas terorisme tersebut. Pendanaan yang didapatkan dari individu maupun kelompok tersebut tidak lain dapat diperoleh dari perdagangan obat-obatan terlarang yang tentunya dijalankan secara ilegal. Hal ini dapat terjadi dikarenakan adanya oknum yang melakukan kecurangan tertentu di dalam institusi legal yang mampu mempermudah mreka dalam melancarkan aktivitas narcoterrorism tersebut.

Narcotrafficking digunakan sebagai metode dalam pendanaan aksi terror dikarenakan akan mendapatkan hasil yang sangat besar dan signifikan. Obat- obatan terlarang di dalam proses produksinya tidak memerlukn dana yang besar dalam produksi secara masalnya, sehingga hal ini menguntungkan dalam aspek cost of benefit yang rendah. Selain biaya produksi yang rendah, obat-obatan terlarang seperti opium dan ganja dapat diproduksi secara berkelanjutan dengan jumlah prodksi yang besar. Praktik narcoterrorism ini sendiri memiliki kemudahan tersendiri dalam jalur akses distribusi karena telah bekerjasama dengan organisasi kejahatan transnasional. Di dalam kasus kali ini, penulis mengambil Triad sebagai salah satu organisasi kejahatan transnasional yang bergerak di bidang perdagangan obat-obatan terlarang, perdagangan senjata, manusia dan berbagai kejahatan lainnya. Di lapangan, jalur distribusi yang digunakan merupakan jalur perdagnagn senjata serta perdagangan manusia yang dimiliki oleh Triad. Besarnya jangkauan Triad di dunia disebabkan diaspora Tiongkok memberikan kemudahan tersendiri 
dalam pendistribusian narkotika dan senjata.

Selain narcoterrorism di atas yang dapat menghubungkan kelompokkelompok teroris transnasional tersebut, kini terdapat penyulundupan dan perdagangan senjata illegal. Di dalam pendistribusiannya, tidak akan berbeda jauh dengan narcoterrorism. Namun, di saat senjata-senjata tersebut telah tiba di negara yang telah dituju, banyak pelaku yang terlibat agar senjata tersebut sampai ke tangan 'pemesan'. Sebagai contoh di Nigeria, para penjaga perdamaian yang tidak bermoral kerap kali meloloskan senjata-senjata illegal di perbatasan sehingga masuk ke Nigeria dan diterima oleh salah satu kelompok teroris di sana, yaitu Boko Haram. Boko Haram tidak hanya mendapatkan senjatanya dari kerjasamanya dengan Triad, tetapi juga dibantu oleh Al-Qaeda, mengingat letak Nigeria yang dekat dengan Somalia dan Maghreb Union yang didominasi oleh Al-Qaeda. Selain itu, sekali lagi Triad yang berada di Afrika Selatan membantu pendistribusian jalur darat tersebut. Berikut alur masuk persenjataan illegal di Afrika Utara.

Figure 1: Jalur Penyelundupan Senjata di Afrika

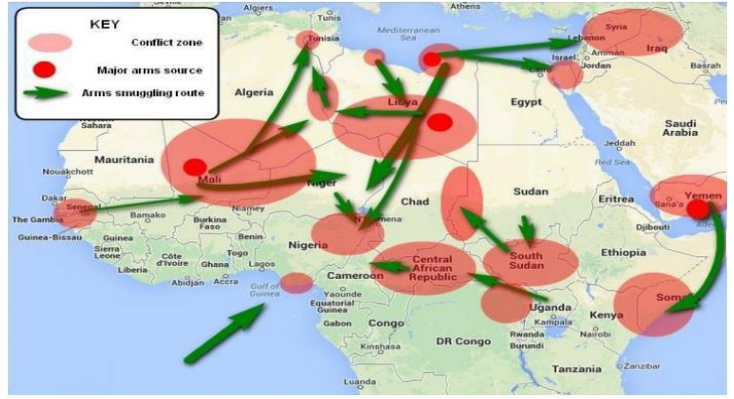

Sumber: (Brett, 2014)

Boko Haram yang terletak di Nigeria menjadi sasaran empuk bagi para pelaku penjual senjata api illegal. Hal ini dikarenakan masih terdapat adanya gejolak internal di Nigeria. Selain adanya konflik di Nigeria, kondisi geografis Nigeria sendiri sangatlah mendukung. Di daerah perbatasan antara sub sahara dan sahara utara terdapat sebuah jalur perdagangan biasa, namun kondisinya yang tidak memungkinkan untuk menjadi sebuah jalur perdagangan biasa membuatnya menjadi jakur penyelundupan senjata illegal. Book Haram yang mendapatkan dukungan dari Al-Qaeda pun tidak hanya dari senjata tetapi juga pelatihan militer di Sahel. Wilayah Maghreb Union yang 
telah dikuasai Al-Qaedapun turut menambah pasokan senjata yang masuk ke Nigeria.

\section{Skema Narcoterrorism dan Perdagangan Senjata Ilegal sebagai Penghubung Jaringan Terorisme Internasional}

Dari pemaparan di atas, maka terlihat jelas bahwa kelompok teroris yang satu dengan kelompok teroris yan lain di berbagai belahan dunia saling terhubung. Meskipun keterhubungan tersebut tidak secara nyata terlihat atau kelompok tersebut menyatakan bergabung, tetapi alur kebutuhan mereka akan persenjataan mereka sama. Keterhubungan jaringan terorisme internasional tersebut dapat terlihat dari gambar di bawah.

Figure 2: Skema Hubungan Jaringan Terorisme Internasional

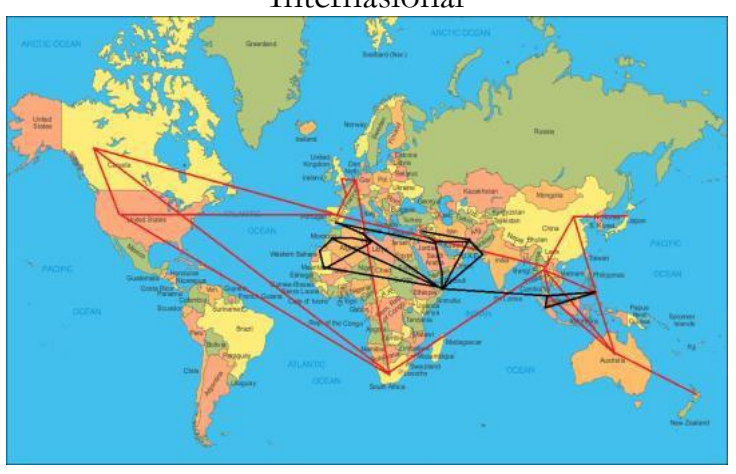

Dari gambar di atas, maka dapat terlihat 3 bentangan garis yang berbeda warna, yakni merah, hitam dan abu- abu. Merah menandakan alur pengiriman senjata illegal dan obatobatan terlarang dari dan ke berbagai cabang Triad yang ada di seluruh dunia, Hitam menandakan hubungan kelompok teroris Al-Qaeda dan kelompok-kelompok yang mendukungnya, antara lain a) Boko Haram, Vanguard for The Protection of Muslims in Blacklands (Nigeria); b) negara-negara yang berada di kawasan Maghreb Union; c) Abu Hats-Al Masri Brigades (Spanyol); d) Tahrir Al-Sham dan Khorasan Group (Suriah); e) Taliban Afganistan (Afganistan); f) Taliban dan Laskar e-Taiba (Pakistan); Tazim Qaedant al-Jihad (Malaysia); g) Jemaah Islamiyah (Indonesia); i) Abu Sayaf (Filipina), dan abu-abu menandakan jaringan basis ISIS.

Jika dijabarkan secara terperinci, senjata illegal akan dikirimkan dari China ke Filipina, kemudian di bawa lagi ke kawasan Golden Triangle Asia, yaitu Thailand, Vietnam, dan Myanmar. Dari golden triangle senjatasenjata tersebut kembali dikirim ke Malaysia, Singapur, Indonesia, Australia dan Selandia Baru. Dari golden 
triangle juga senjata-senjata tersebut di bawa ke kawasan golden crescent dan melalui tanduk afrika (Somalia), serta Afrika Selatan. Dari Afrika Selatan inilah senjata kembali didistribusikan ke Amerika dan Kanada.

\section{KESIMPULAN}

Akibat dari cara pencarian dana yang ilegal oleh teroris maka secara tidak langsung jaringan teroris satu dengan yang lainnya terhubung melalui bisnis gelap tersebut. narcoterrorism menjadi sebuah bisnis yang menguntungkan baik bagi teroris maupun kartel yang bekerja sama dengan para teroris tersebut. Dengan para teroris menyuplai narkoba kepada mereka sebagai gantinya mereka harus menyediakan senjata untuk keperluan para teroris, hubungan yang saling menguntungkan ini dilakukan hampir oleh setiap jaringan teroris yang ada karena mereka akan kesulitan jika mencari pendanaan melalui jalur lainnya. Jadi secara tidak langsung hampir semua teroris di dunia terhubung melalui bisnis ilegal ini baik mereka mengetahuinya ataupun tidak.

\section{DAFTAR PUSTAKA}

African Union. (2017) Boko Haram, Teroris Mematikan Asal Nigeria Penerus ISIS Di Afrika (Online). Tersedia di: http://www.african-union.org/bokoharam-teroris-mematikan-asal-nigeriapenerus-isis-di-afrika/ (diakses 11 Agustus 2017).

BBC Indonesia. (2014) Siapa Saja yang Kini Memimpin Al-Qaida? (Online). Tersedia di:

http://www.bbc.com/indonesia/duni a/2014/12/141208_alqaida_pemimpi n (Diakses: 9 Juli 2017).

BBC Indonesia. (2015) FBI Umumkan Kematian Pimpinan Jemaah Islamiyah (Online). Tersedia di: http://www.bbc.com/indonesia/duni a/2015/04/150402_dunia_kematian_j emaah_islamiah (Diakses: 9 Juli 2017).

BBC News. (2014) Syria Iraq: The Islamic State Militant Group [Online]. Tersedia di:

http://www.bbc.com/news/worldmiddle-east-24179084/ [Diakses: 2 Agustus 2017].

Brett, D. (2014) Boko Haram: Military Is The Problem, Not the Solution (Online). Tersedia di: http://www.huffingtonpost.co.uk/da niel-brett/boko-haram-nigerianmilitary_b_5490105.html (Diakses: 9 Juli 2017).

CISAC, (2018) Mapping Militant Organizations (Online). Tersedia di: http://web.stanford.edu/group/map pingmilitants/cgi-

bin/groups/view/152 (Diakses: Juni 2017).

Fahrudin. (t.t) Fenomena Jama'ah Islamiyah di Asia Tenggara: Sebuah Gerakan Jihad Internasional (Online). Tersedia di:

http://file.upi.edu/Direktori/FPIPS/ M_K_D_U/195910081988031-

FAHRUDIN/JAMA\%27AH_ISLAM IYAH.pdf (Diakses: Tanggal 9 Juli 
2017).

Hutchinson, A. (2002) International Drug Trafficking and Terrorism (Online). Tersedia di https://20012009.state.gov/p/inl/rls/rm/9239.ht m (Diakses: 9 Juli 2017).

J.T. Caruso. (2001) Al-Qaeda Internasional (Online) Tersedia di: https://archives.fbi.gov/archives/ne ws/testimony/al-qaeda-international (Diakses: 8 Desember 2017).

Kuncahyo, T. (2013) Politik Luar Negeri Indonesia dan Kerjasama Transnasional Melawan Terorisme. Hasil diskusi terfokus Politik Luar Negeri Indonesia dan Isu Terorisme Internasional, Jakarta: P2P LIPI.

Levitt, M. (2005) Hębollab: Financing Terror Through Criminal Enterprise, United States: The Washington Institute for Near East Policy.

Nahdlaltul Ulama. (2014) Bagaimana Sejarah Terbentuknya ISIS? (Online). Tersedia di:

http://www.nu.or.id/post/read/5366 9/bagaimana-sejarah-terbentuknya-isis (Diakses: 6 Agustus 2017).
National Geographic Indonesia. (2014) Bagaimana Kisab Awal ISIS Terbentuk? (Online). Tersedia di: http://nationalgeographic.co.id/berita /2014/07/bagaimana-kisah-awal-isisterbentuk (Diakses: 9 Juli 2017).

Sahisnu, F. H. (t.t) Keamanan Nasional Nigeria dan Ancaman Global; Organisasi Teroris Boko Haram (Online). Tersedia di: http://www.academia.edu/10196036 /Keamanan_Nasional_Nigeria_dan_ Ancaman_Global_Organisasi_Teroris _Boko_Haram (Diakses: 9 Juli 2017).

Walker, A. (2012) What Is Boko Haram? United States Institute of Peace, Special Report, No. 308, Washington DC, p.3.

Wuryandari, G., ddk. (2014) Politik Luar Negeri Indonesia dan Isu Terorisme Internasional, Yogyakarta: Graha Ilmu. 